\title{
Efficacy and Safety of Erlotinib in Previously Treated Advanced Non-Small Cell Lung Cancer
}

\author{
Halit KARACA ${ }^{1}$, Caglayan GEREDELI ${ }^{2}$, M. Ali KAPLAN ${ }^{3}$, Umut DEMIRCI ${ }^{4}$, Suleyman ALICI ${ }^{5}$, \\ Mehmet ARTAC ${ }^{2}$, Abdurrahman ISIKDOGAN ${ }^{3}$, Mustafa BENEKLI ${ }^{4}$, Ozan BALAKAN ${ }^{6}$, \\ Erkan ARPACI ${ }^{7}$, Burcin BUDAKOGLU ${ }^{8}$, Dogan UNCU ${ }^{9}$, Tunc GULER ${ }^{2}$, Veli BERK ${ }^{1}$, Metin OZKAN ${ }^{1}$
}

\author{
${ }^{1}$ Erciyes University Faculty of Medicine, Department of Medical Oncology, Kayseri \\ ${ }^{2}$ Selcuk University Meram Faculty of Medicine, Department of Medical Oncology, Konya \\ ${ }^{3}$ Dicle University Faculty of Medicine, Department of Medical Oncology, Diyarbakir \\ ${ }^{4}$ Gazi University Faculty of Medicine, Department of Medical Oncology, Ankara \\ ${ }^{5}$ Medical Park Goztepe Hospital, Department of Medical Oncology, Istanbul \\ ${ }^{6}$ Gaziantep University Faculty of Medicine, Department of Medical Oncology, Gaziantep \\ ${ }^{7}$ Ankara Oncology Hospital, First Department of Medical Oncology- Ankara \\ ${ }^{8}$ Ankara Oncology Hospital, Second Department of Medical Oncology, Ankara
}

${ }_{9}^{9}$ Ankara Numune Training and Research Hospital, Department of Medical Oncology, Ankara, TURKEY

\begin{abstract}
Erlotinib is a potent inhibitor of the epidermal growth factor receptor (EGFR) tyrosine kinase, with single-agent antitumor activity which improves symptom control and quality of life compared with placebo in non-small-cell-lung cancer (NSCLC) patients. We aimed to determine the efficacy and safety of the second, third or fourth-line erlotinib in advanced NSCLC patients in Turkish population.

Eighty patients (33 males and 47 females) were retrospectively evaluated. All patients had received a platinum-based regimen as the first-line metastatic therapy. Most of the patients (62.5\%) had received erlotinib as the second-line treatment. None of the patients had EGFR mutation studied. One patient achieved a complete response, 10 patients partial response and 21 stable diseases. The overall response rate was $14 \%$ and disease control rate was $40 \%$. The median progression-free survival (PFS) and overall survival (OS) were 12 months and 18 months, respectively. Although, there was no survival difference between male and female patients, the median PFS of females was significantly better than male patients $(p=0.03)$. There was no significant difference in disease control rate in terms of age, smoking status, erlotinib line, performance status (PS), stage and skin rash. The most common adverse events were skin rash (56\%), diarrhea (9\%) and anorexia (8\%). Sixteen patients (20\%) developed grade 3 toxicities. Grade 4 toxicity or treatment related interstitial lung disease were not observed. Erlotinib showed an acceptable response rate, survival time and toxicity after disease progression with chemotherapy. It's an alternative therapy as a second or third-line therapy in patients with NSCLC. Prospective studies are needed to evaluate the efficiency of the treatment in Turkish population.
\end{abstract}

Keywords: Non-small-cell lung cancer, Targeted therapy, Erlotinib, Epidermal growth factor receptor

ÖZET

Daha Önce Tedavi Edilmiş İleri Evre Küçük Hücreli Dışı Akciğer Kanserli Hastalarda Erlotinibin Güvenlik ve Etkinliği

Erlotinib tek başına anti-tümör aktiviteye sahip olan güçlü bir epidermal büyüme faktör reseptörü tirozin kinaz inhibitörüdür ve küçük hücreli dışı akciğer kanseri hastalarında plasebo ile karşılaştıııdığında semptom kontrolü ve yaşam kalitesini iyileştirmektedir. Çalışmamızda, Türk popülasyonunda, ileri evre NSCLC hastalarında ikinci, üçüncü veya dördüncü sıra erlotinib tedavisinin etkinlik ve güvenirliliğini retrospektif olarak değerlendirmeyi amaçladık. 
Çalışmaya 33 erkek ve 47 kadın, toplam 80 hasta dahil edildi. Tüm hastalar metastatik ilk sırada platin-temelli kemoterapi rejimi almışlardı ve hastaların çoğu (\%62.5) erlotinibi ikinci sırada kullanmışlardı. Hiçbir hastada EGFR mutasyonu çalışılamadı. Bir hastada tam cevap, 10 hastada parsiyel cevap ve 21 hastada stabil hastalık mevcut idi. Genel cevap oranı \%14 ve hastalık kontrol oranı \%40 idi. Ortanca progresyonsuz sağkalım ve genel sağkalım sırasıyla 12 ay ve 18 ay olarak tespit edildi. Her nekadar, erkek ve kadın hastalar arsında genel sağkalım farkı olmasa da, kadın hastaların ortanca progresyonsuz sağkalımı istatistiksel olarak erkek hastalardan dahi iyiydi ( $p=0.03)$. Hastalık kontrol oranı ile yaş, sigara alışkanlığı, erlotinib sırası, performans durumu, başlangıç evresi ve rash arasında istatistiksel bir ilişki tespit edilemedi. En sık görülen yan etkiler döküntü (\%56), ishal (\%9) ve anoreksi (\%8) idi. On altı hastada (\%20) grad 3 toksisite gelişmişti. Grad 4 toksisite veya tedavi ilişkili interstisiyel akciğer hastalığı gözlenmedi. Erlotinib, kemoterapi sonrası hastalık progresyonunda kabul edilebilir cevap oranı, sağkalım süresi ve toksisite göstermektedir. NSCLC hastalarında ikinci veya üçüncü basamak tedavide alternatif bir seçenek olabilir. Türk toplumunda etkinliğini değerlendiren prospektif çalışmalara intiyaç vardır.

Anahtar Kelimeler: Küçük Hücreli Dışı Akciğer Kanseri, Hedefe yönelik tedavi, Erlotinib, Epidermal büyüme faktör reseptörü

\section{INTRODUCTION}

Lung cancer is the second most common cancer among men and women and the most common cause of cancer death in the world1. Non-small cell lung cancer (NSCLC) represents about $85 \%$ of all lung cancer cases and is generally diagnosed at advanced stage. First line treatment of advanced NSCLC is based on the platinum-doublet chemotherapy with a median overall survival (OS) of about 10-12 months. ${ }^{2,3}$ As the number of patients receiving first-line chemotherapy increases, the need for effective second, third or even fourth-line therapy has been increasing. Advanced NSCLC patients also with poor performance status (PS) tend to have worse response rates and higher risk of toxicities following chemotherapy treatment.,

Intracellular signaling activated by the EGFR plays a role in tumor growth and progression in cancer and EGFR overexpression is seen in up to $80 \%$ of NSCLC6,7. Erlotinib is a potent, orally active, reversible inhibitor of EGFR tyrosine-kinase activity and have received approval for the treatment of advanced NSCLC worldwide. ${ }^{8-11}$ Recently, studies of erlotinib demonstrated promising efficacy and favorable toxicity. ${ }^{12-14}$ In a large, randomised, placebo-controlled, phase III trial (BR.21) in patients with advanced NSCLC who had previously received at least one chemotherapy regimen, erlotinib monotherapy significantly prolonged survival compared with placebo. ${ }^{8}$ As compared with placebo, treatment with erlotinib resulted in a significantly longer progression-free survival (PFS) (2.2 vs. 1.8 months; hazard ratio (HR): $0.6 ; \mathrm{p}<0.001)$ and $\mathrm{OS}$ (6.7 vs. 4.7 months; (HR: 0.70; $\mathrm{p}<0.001$ ).

There is no data about erlotinib treatment in NSCLC in Turkey. This retrospective study aimed to determine the efficacy and safety of second, third or fourth-line erlotinib in advanced NSCLC patients regardless of EGFR mutation.

\section{PATIENTS AND METHODS}

We retrospectively evaluated the outcome and clinical characteristics of unselected patients treated with erlotinib for advanced NSCLC. Eighty patients with metastatic NSCLC treated with erlotinib $150 \mathrm{mg}$ daily after failure of at least one prior chemotherapy regimen between May 2006 and August 2011 from 9 centers were retrospectively evaluated. Medical records were reviewed to collect demographic data, Eastern Cooperative Oncology Group (ECOG) PS, lung cancer histology, history of tobacco use, metastatic sites, previous chemotherapy, radiotherapy, line of erlotinib treatment, efficacy data and toxicities. Smoking status was defined as never smoker, former smoker ( $>100$ cigarettes in life, but stopped more than six months ago) and current smoker (continuing smoking during the last six months). Although majority of our patients had adenocarcinoma histology, female sex and never smoker due to reimbursement conditions in Turkey, four patients $(5 \%)$ who were current smoker used the erlotinib as a study drug.

The following factors were evaluated for a potential influence on the response and disease control rate: age ( $\leq 40,40-60$ years versus $\geq 60$ ), gender (male versus female), PS, initial disease stage, smoking status (current smoker versus former smoker/never smoker), histology (adenocarcinoma histology versus others), line of erlotinib treatment and grades of rash $(0 / 1$ versus $2+)$. PFS and OS were calculated after the initiation of erlotinib. 
All values were analyzed using SPSS 15.0 software. All comparisons were performed by means of the Fisher's exact test and correlations evaluated by the Pearson Chi-Square test. Survival data was estimated by the Kaplan-Meier method. P values of $<0.05$ were considered significant.

\section{RESULTS}

There were 80 patients: 33 males and 47 females. Demographic data and main characteristics of the patients are shown in Table 1. Most patients (66\%) had ECOG PS 0 and 1 with a predominance of adenocarcinoma histology (91\%). All patients had received a platinum-based regimen as the first-line metastatic therapy. Most of the patients $(62.5 \%)$ had received erlotinib as the second-line treatment. The most common metastatic sites were bone $(31 \%)$ and brain $(24 \%)$. Eighteen patients $(23 \%)$ had multiple metastatic sites. Six patients $(8 \%)$ had relapsed after curative surgery and 18 patients $(23 \%)$ after curative chemoradiotherapy. Sixty-six patients $(82.5 \%)$ had never smoked. None of the patients had their EGFR mutation status determined.

The median folow-up period was 10 months (range, 2-37) after the beginning of erlotinib treatment. The median duration of erlotinib treatment was 6 months (range, 2-37). One patient had a complete response (CR), 10 patients achieved partial response (PR) and 21 had stable disease (SD). The overall response rate was $14 \%$ and disease control rate (DCR=ORR+SD) was $40 \%$. At the time of analysis, there were $32(40 \%)$ deaths and 27 patients (34\%) were still on erlotinib. There was no significant difference in DCR in terms of age, smoking status, erlotinib line, PS, initial stage and skin rash but significance was borderline in female patients (female $49 \%$ vs. male $27 \%, \mathrm{p}=0.052$ ).

The median PFS and OS were 12 months (95\% CI: 4.22-19.78 months) and 18 months (95\% CI:13.3422.76 months), respectively (Figure 1 and 2). Analysis of prognostic factors showed that only PS was significantly correlated with OS $(p=0.004)$. Although, there was no OS difference between male and female patients, the median PFS of females was significantly better than male patients (18 vs. 5 months, $\mathrm{p}=0.03$, Figure 3 ).

\begin{tabular}{|c|c|c|}
\hline & $\mathbf{n}$ & $\%$ \\
\hline \multicolumn{3}{|l|}{ Gender } \\
\hline Male & 33 & 41 \\
\hline Female & 47 & 59 \\
\hline \multicolumn{3}{|l|}{ Age, years } \\
\hline Median, range & $58(28-78)$ & \\
\hline$\leq 40$ & 10 & 12.5 \\
\hline $40-60$ & 32 & 40 \\
\hline$\geq 60$ & 38 & 47.5 \\
\hline \multicolumn{3}{|l|}{ Performance status } \\
\hline 0 & 8 & 10 \\
\hline 1 & 45 & 56 \\
\hline 2 & 25 & 31 \\
\hline 3 & 2 & 3 \\
\hline \multicolumn{3}{|l|}{ Histologic type } \\
\hline Adenocarcinoma & 73 & 91 \\
\hline Squamous cell carcinoma & 4 & 5 \\
\hline Bronchoalveolar cancer & 3 & 4 \\
\hline \multicolumn{3}{|l|}{ Smoking status } \\
\hline Current smoker & 4 & 5 \\
\hline Former smoker & 10 & 12.5 \\
\hline Never smoked & 66 & 82.5 \\
\hline \multicolumn{3}{|l|}{ Initial stage } \\
\hline । & 3 & 4 \\
\hline$\|$ & 3 & 4 \\
\hline III & 18 & 23 \\
\hline IV & 56 & 69 \\
\hline \multicolumn{3}{|l|}{ Erlotinib treatment } \\
\hline Second-line & 50 & 62.5 \\
\hline Third-line & 24 & 30 \\
\hline Fourth-line & 6 & 7.5 \\
\hline \multicolumn{3}{|l|}{ Rash, grade } \\
\hline 0 & 34 & 42 \\
\hline 1 & 11 & 14 \\
\hline 2 & 19 & 24 \\
\hline 3 & 16 & 20 \\
\hline
\end{tabular}

The most common adverse event (AE) was skin rash $(56 \%)$ (Table 2). Diarrhea (9\%) and anorexia $(8 \%)$ were the other common side effects. Sixteen patients $(20 \%)$ developed grade 3 toxicities including rash $(\mathrm{n}=15,19 \%)$ and diarrhea $(\mathrm{n}=1)$. Grade 4 toxicity or treatment related interstitial lung dise- 


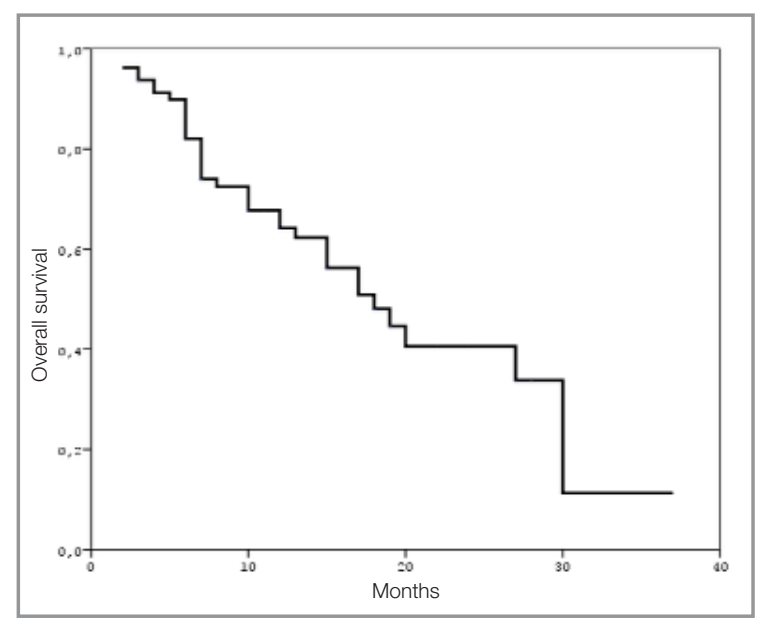

Figure 1. Progression-free survival of the patients treated with erlotinib.

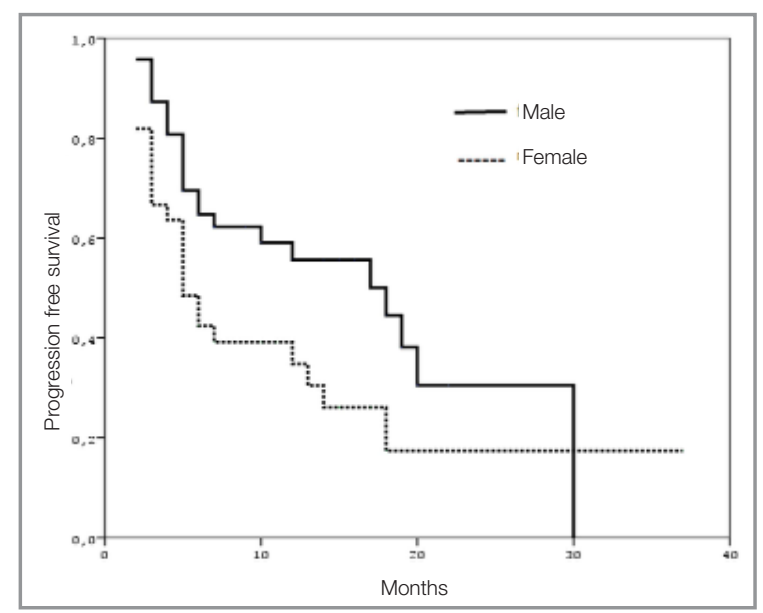

Figure 3. The median PFS of females was significantly better than male patients $(p=0.03)$.

ase (ILD) were not observed. Due to grade 3 toxicities erlotinib treatment was interrupted in 5 patients (10\%) and 3 patients (4\%) required dose reductions. All the side effects were improved after dose reductions or delays with no further dose mo-

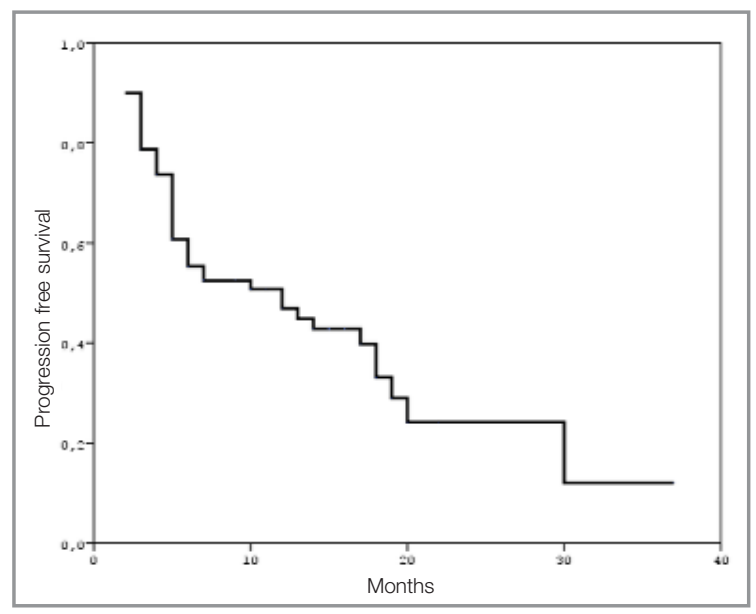

Figure 2. Overall survival of the patients treated with erlotinib

difications. The median duration of treatment interruptions was 10 days.

\section{DISCUSSION}

Only a few options are available for the treatment of patients who are eligible for chemotherapy with disease progression after platin-based chemotherapy for NSCLC. ${ }^{15}$ Clearly, new and effective treatments are needed for such patients. The EGFR tyrosine kinase inhibitors gefitinib and erlotinib have been evaluated in several trials. Recently, erlotinib has been investigated in the TRUST study in patients $(n=6665)$ with advanced stage IIIB/IV NSCLC. ${ }^{16} \mathrm{CR}$, PR and SD rates were $<1 \%, 14 \%$ and $54 \%$, respectively. Of these, 389 patients (12\%) had an erlotinib-related adverse events and only 96 patients (3\%) had $\geq$ grade 3 of AEs. Subgroup analyses demonstrated that PFS and OS were significantly longer in women versus men, in oriental patients versus other ethnic groups, in patients with adenocarcinoma or bronchoalveolar carcinoma ver-

\begin{tabular}{|llllll|}
\hline \multicolumn{7}{|l|}{ Table 2. Common side effects and grades } \\
\hline G (\%) & $\begin{array}{l}\text { Grade 1 } \\
19(24)\end{array}$ & $\begin{array}{l}\text { Grade 2 } \\
23(29)\end{array}$ & $\begin{array}{l}\text { Grade 3 } \\
16(20)\end{array}$ & $\begin{array}{l}\text { Grade 4 } \\
0\end{array}$ & $\mathrm{n}(\%)$ \\
\hline Rash & 11 & 19 & 15 & 0 & $45(56)$ \\
Diarrhea & 5 & 1 & 1 & 0 & $7(9)$ \\
Anorexia & 3 & 3 & 0 & 0 & $6(8)$ \\
\end{tabular}


sus those with squamous-cell carcinoma, and in never-smokers versus former or current smokers. PFS and OS were also significantly longer in patients with ECOG PS of 0 or 1 versus those with PS of 2 or 3 and in patients who developed erlotinib-related rash compared to those with no rash. The line of treatment (second or third line) was not found to be a prognostic factor for efficacy in the same analysis for the overall population. The findings of TRUST, together with those of BR.21, indicate that erlotinib is as effective as conventional chemotherapy in terms of disease control and survival advantage in patients with advanced NSCLC who had previously failed chemotherapy.

In our study, one patient had a CR, 10 patients achieved PR and 21 had SD, overall DCR (40\%) observed in our patients were similar to these of the BR.21 trial. We found that, the median PFS and OS were 12 months (95\% CI: 4.22-19.78 months) and 18 months (95\% CI:13.34-22.76 months), respectively. These results are better than BR.21 and TRUST data. However, in another retrospective study $^{17}$, median PFS and OS were reported as 4 and 15 months, respectively. Our good results may be due to limitations of the study such as small study population and retrospective nature. Other reasons might be the presence of good prognostic and predictive factors for erlotinib treatment such as adenocarcinoma histology, good PS, female sex and never smokers mentioned in other trials. ${ }^{8,16}$

In several trials, patients with the highest probability of benefit from erlotinib appeared to be females, never smokers, Asian ethnicity with adenocarcinoma histology, with good PS and in patients who developed erlotinib-related rash. ${ }^{8,16,17}$ In our study, most of the patients $(59 \%)$ were females, non-smokers $(82.5 \%)$ with ECOG PS 0 and $1(66 \%)$ and skin rash $(56 \%)$ who had received erlotinib as the second-line treatment $(62.5 \%)$. There was no significant difference in the DCR in terms of age, smoking status, erlotinib line, PS, initial stage and skin rash. But, female patients had a marginally better DCR compared to males ( $49 \%$ vs. $27 \%, \mathrm{p}=0.052$ ). Analysis of prognostic factors showed that only PS was significantly correlated with OS $(p=0.004)$. Although, there was no OS difference between male and female patients, the median PFS of females was significantly better than male patients (18 vs. 5 months, $\mathrm{p}=0.03$ ). Although, none of our patients were tested for EGFR mutation, it's known that female patients have higher EGFR mutation rate. ${ }^{18}$ In our study, better efficacy results in females may be explained by the presence of higher rates of EGFR mutations. Therefore, in cases whose EGFR mutation can not be analyzed, these patients should not be excluded from erlotinib treatment.

Skin rash and diarrhea are the most common sideeffects of erlotinib. ILD and pulmonary fibrosis are the SAE's related to erlotinib treatment with an incidence of $<1 \% .{ }^{19}$ In our study, erlotinib had a favorable toxicity profile, and the percentage of patients who required erlotinib dose reductions (4\%) was quite low. Erlotinib was generally well tolerated, thus enabling the majority of patients to receive the full therapeutic dose. The most common adverse event was skin rash (56\%). Only 16 patients (20\%) developed grade 3 toxicities. Grade 4 toxicity or treatment related ILD were not observed. Due to grade 3 toxicities erlotinib treatment was delayed in 5 patients $(10 \%)$ and 3 patients $(4 \%)$ required dose reductions. AEs were tolerable and seemed to be equivalent to those in the other population as reported previously, but the incidence of ILD in our study was much lower than that observed in the BR.21 study. Careful management of AEs of erlotinib enables optimum treatment of the patients resulting in increased efficacy.

Rosell et al..$^{20}$ analyzed the association between EGFR mutations and the outcome of erlotinib treatment, reporting a PFS of 14 months and overall survival of 27 months in EGFR mutant patients treated with erlotinib. Recently published data from EURTAC phase III study ${ }^{21}(\mathrm{n}=174)$ demonstrated that, median PFS 9.7 months (95\% CI, 8.4-12.3) in the erlotinib group, compared with 5.2 months $(95 \%$ CI, 4.5-5.8) in the standard chemotherapy group $(p<0.0001)$. These studies clearly suggest that EGFR mutations should be determined in patients with NSCLC and only those patients positive for mutations should be considered for treatment with EGFR-TKI. However, we were not able to assess EGFR mutation in any of the patients. Despite this, careful selection of the study population might have probably led to these superior results.

In conclusion, although limited by small numbers and its retrospective design, our study confirmed that erlotinib induces high DCR in pretreated 
NSCLC patients with manageable side effects. Future prospective studies should include molecular markers together with other biologic and clinical parameters to further improve selection of patients treated with EGFR tyrosine-kinase inhibitors.

\section{REFERENCES}

1. Siegel R, Ward E, Brawley O, Jemal A. Cancer Statistics 2011, The Impact of Eliminating Socioeconomic and Racial Disparities on Premature Cancer Deaths. CA Cancer J Clin 61: 212-236, 2011.

2. Non-small Cell Lung Cancer Collaborative Group. Chemotherapy in non-small cell lung cancer: a metaanalysis using updated data on individual patients from 52 randomised clinical trials. BMJ 31: 899-909, 1995.

3. Ramalingam S, Belani CP. Systemic chemotherapy for advanced non-small cell lung cancer: recent advances and future directions. Oncologist 13 (suppl 1): 5-13, 2008.

4. Billingham LJ, Cullen MH. The benefits of chemotherapy in patient subgroups with unresectable non-smallcell lung cancer. Ann Oncol 12: 1671-1675, 2001.

5. Soria JC, Brisgand D, Le CT. Do all patients with advanced non-small-cell lung cancer benefit from cisplatin-based combination therapy? Ann Oncol 12: 16671670, 2001.

6. Salomon DS, Brandt R, Ciardiello F, Normanno N. Epidermal growth factor-related peptides and their receptors in human malignancies. Crit Rev Oncol Hematol 19: 183-232, 1995.

7. Hirsch FR, Varella-Garcia M, Bunn PA Jr, et al. Epidermal growth factor receptor in non-small-cell lung carcinomas: correlation between gene copy number and protein expression and impact on prognosis. $\mathrm{J}$ Clin Oncol 21: 3798-3807, 2003.

8. Shepherd FA, Rodrigues PJ, Ciuleanu T, et al. Erlotinib in previously treated non-small-cell lung cancer. $\mathrm{N}$ Engl J Med 353: 123-132, 2005.

9. Thatcher N, Chang A, Parikh P, et al. Gefitinib plus best supportive care in previously treated patients with refractory advanced non-small-cell lung cancer: results from a randomized, placebo-controlled, multicentre study (Iressa survival evaluation in lung cancer). Lancet 366: 1527-1537, 2005.

10. Lin CC, Yang $\mathrm{CH}$. Epidermal growth factor receptor tyrosine kinase inhibitors in elderly or poor performance status patients with advanced non-small cell lung cancer. Target Oncol 4: 37-44, 2009.

11. Langer CJ. The "lazarus response" in treatment-naive, poor performance status patients with non-small-cell lung cancer and epidermal growth factor receptor mutation. J Clin Oncol 27: 1350-1354, 2009.

12. Spigel DR, Hainsworth JD, Burkett ER, et al. Singleagent gefitinib in patients with untreated advanced non-small-cell lung cancer and poor performance status: a minnie pearl cancer research network phase ॥ Trial. Clin Lung Cancer 7: 127-132, 2005.
13. Hesketh PJ, Chansky K, Wozniak AJ, et al. Southwest oncology group phase II trial (S0341) of erlotinib (OSI-774) in patients with advanced non small cell lung cancer and a performance status of 2 . J Thorac Oncol 3: 1026-1031, 2008.

14. Ishibe N, Carlson J, Ramsey SD, et al. Use of epidermal growth factor receptor mutation analysis in patients with advanced non-small-cell lung cancer to determine erlotinib use as first-line therapy. PLoS Curr 21: 1-6, 2011.

15. Shepherd FA, Dancey J, Ramlau R, et al. A prospective randomized trial of docetaxel versus best supportive care in patients with non-small-cell lung cancer previously treated with platinum-based chemotherapy. J Clin Oncol 18: 2095-2103, 2000.

16. Heigener DF, Wu YL, van Zandwijk N, et al. Secondline erlotinib in patients with advanced non-small-celllung cancer: Subgroup analyses from the TRUST study. Lung Cancer 74: 274-279, 2011.

17. Mazzoni F, Rotella $\mathrm{V}$, Pratesi N, et al From clinical trials to clinical practice: predictors of response to erlotinib in advanced non-small cell lung cancer patients pretreated with chemotherapy. Tumori 97: 160-165, 2011.

18. Zhou $\mathrm{C}, \mathrm{Wu} \mathrm{YL}$, Chen $\mathrm{G}$, et al. Erlotinib versus chemotherapy as first-line treatment for patients with advanced EGFR mutation-positive non-small-cell lung cancer (OPTIMAL, CTONG-0802): a multicentre, open-label, randomised, phase 3 study. Lancet Oncol 12: 735-742, 2011.

19. Inoue A, Saijo Y, Maemondo M, et al. Severe acute interstitial pneumonia and gefitinib. Lancet 361: 137139, 2003.

20. Rosell R, Moran T, Queralt C, et al. Screening for epidermal growth factor receptor mutations in lung cancer. N Engl J Med 361: 958-967, 2009.

21. Rosell R, Carcereny E, Gervais R, et al. Erlotinib versus standard chemotherapy as first-line treatment for European patients with advanced EGFR mutationpositive non-small-cell lung cancer (EURTAC): a multicentre, open-label, randomised phase 3 trial. Lancet Oncol 13: 239-246, 2012.

\section{Correspondence}

Dr. Halit KARACA

Erciyes Üniversitesi Tıp Fakültesi

M. Kemal Dedeman Onkoloji Hastanesi

Talas

KAYSERI / TURKEY

Tel: (+90.352) 4375148

Fax: (+90.352) 4375148

e-mail: halitraca@hotmail.com 